Journal of Urban and Regional Analysis, vol. XIII, 1, 2021, p. 77 - 91

https://doi.org/10.37043/JURA.2021.13.1.5

\title{
DISCOURSES ON SPAIN'S HOUSING CRISIS: A TYPOLOGICAL PROPOSAL
}

\author{
Estefanía CALO, Raimundo OTERO-ENRÍQUEZ, Alberto RODRÍGUEZ-BARCÓN \\ University of A Coruña, A Coruña, Spain
}

\begin{abstract}
The recent economic crisis has had serious consequences on the housing system, making it necessary to rethink housing in our society from a multidisciplinary and multi-methodological point of view. Purely quantitative studies are insufficient to analyse the structural and social aspects of housing: it is necessary to define concepts, extent approaches and to understand that residential studies should also resort to qualitative analyses to achieve a further understanding of the situation. This paper is based on the analysis of 35 focused interviews about Spain's housing crisis. The results show that there are only two discursive types: a critical discourse and a conservative discourse. In the dialectical confrontation of both views, some key factors for understanding the housing market are left out, which may lead to a new crisis scenario.
\end{abstract}

Key Words: housing, crisis, discourses, Spain.

Introduction

Currently, in Spain, housing and the construction of urban centres absorb the capitalist surplus and they stabilize the economy. The former, our core research interest, has become a global phenomenon that has depended on new institutions and financial devices to organize the necessary credit to sustain it, such as the securitization and serialization of local mortgages. These have dispersed the risk and created a fund of easily accessible surplus savings for the housing demand, they lowered the global interest rates and they generated wealth for the intermediaries: "The lack of control over risk assessment led to a double crisis: the subprime and the value of real estate assets" (Harvey 2008: 30). According to Nel-Lo (2019), this situation has produced a global change in social relations, reducing them to commercial criteria, with private profit being the element that regulates the production and distribution of goods and services. Furthermore, it has generated a new urban system in which large cities become nodes of the international system with more suburbanization, metropolitanisation, impoverishment and greater social, economic and spatial inequalities (Sassen 1999, Castells 2004, Sassen 2004).

This neoliberalisation and financialisation of housing provision were promoted by international financial institutions like the World Bank (Van Waeyenberge 2018). The main aim was to encourage home ownership and financial asset-based welfare. However, this political economy did not regulate high-risk lending, fuelling both an unsustainable housing boom and a toxic asset bubble of housing-backed financial instruments such as subprime mortgage (Fields and Hodkinson 2018). According to Aalbers (2015), this lack of regulation is one of the main causes behind the global financial crisis (GFC) and its global repercussions after the collapse of Lehman Brothers in 2007 (Etxezarreta Etxarrri et al. 2012) and the crisis of the subprime mortgage in the United States that cut off the easy, abundant and cheap bank financing to the real estate sector (Burriel de Orueta 2016). As Martin (2011: 587) states, this shift from a "locally originate, locally-hold" model of mortgage provision to a securitized "locally originate, globally distribute" model meant that when local subprime mortgage markets collapsed in the United States, the repercussions were felt globally. 
From an international perspective, housing crises are a consistent element of a capitalist political economy based on private property, market exchange, and the accumulation of capital (Fields and Hodkinson 2018). The GFC casts serious doubt on the ability of national authorities to manage the protection of investors and households (Martin 2011). According to Aalbers (2015), capitalism has become increasingly dependent on the growth of finance. The post-2007 housing crisis has been the first global housing crisis in the sense that never before have so many countries faced a housing crisis at the same time.

Therefore, the role of housing in global capitalist economies and societies needs to be closely considered (Ferrari 2015). Housing has different dimensions that are fundamental for our society. On the one hand, it has a social dimension considered as a basic need and a right. On the other hand, it has an economic dimension, as it is also an investment asset. As such, it is vulnerable not only to changes in the financial market, but also to the models of social regulation and to the crises of capital accumulation. In this sense, housing is regarded as part of the families' assets and as an investment opportunity (Leal Maldonado and Cortés Alcalá 1995), capitalizing family incomes by its transmission through inheritance and by its economic value.

\section{Housing system and crisis in Spain}

The depth of the last Spanish housing crisis is reflected in the collapse of the construction field and in the number of housing and land stocks (Burriel de Orueta 2016), but with some peculiarities. The Spanish expansive cycle was longer than the rest of the European Union because Spain had an economic model based on the real estate sector (García Montalvo 2009, Naredo 2010, López and Rodriguez 2013). According to Módenes and López-Colás (2014), this can be related with a Spanish familialist welfare state (Esping-Andersen 1990) characterised by a high commodification of goods and basic services such as housing; a relatively high social stratification; and by a system of provision in which the family has a dominant position. In relation to housing policies, Bermejo Latre (2010) indicates that since 1939 the legal and financial state policies have focused on building a proprietary middle class, strongly stimulating house ownership (Gaja I Díaz 2013). In this sense, housing has not evolved like other basic rights, such as education and health, but it has been instituted as an inheritable asset that should be transmitted within the family, creating a system that is based on the property as an axis key. This logic has generated a model that depends more on economic issues than on the population's needs. Thus, there has been a deterioration in the housing culture "where the concept of housing as a commodity prevails to the detriment of its consideration as a need and use value" (Cortés Alcalá 1997: 57).

Spain's joining the EEC in 1986 and the adoption of the euro as a common currency in 1999 had an effect on the creation of the 2007 real estate crisis (Rodríguez López 2013). In 1998, the end of the previous crisis was confirmed, mainly driven by the introduction of the euro. There were improvements in financing and the home purchase effort for families fell from $48 \%$ in 1995 to $27 \%$ in 1999. It is estimated that, between 1999 and 2002, an overvaluation of house prices of around $28 \%$ occurred. It is considered that $13 \%$ was an effect of the adoption of the euro and $15 \%$ is attributed to the expectations of revaluation of housing prices (Garcia Montalvo 2003).

In the context of these commercial and socio-cultural values, in the first years of the 21st century, a remarkably intense economic growth took place in Spain. It was dependant on speculation in the house building sector between 2005 and 2008, when more than four and a half million new houses were built (Fig. 1). In this sense, the creation of the real estate bubble was the consequence of financing conditions, monetary policy and policies to promote home purchases. The conditions of interest rates, repayment terms and the loan/value ratio pushed prices beyond justification (García Montalvo 2006, García Montalvo 2007). The relationship between the construction and banking industries created a speculative structure between 1997 
and 2007 (Naredo 2010), which has led to the most expansive cycle in the last forty years (Miguel 2009, Naredo and Montiel Márquez 2011), resulting, in turn, in an increase in prices, forcing households to get into debt (Miguel 2009, Naredo 2010, Naredo and Montiel Márquez 2011). Moreover, it imposed a vision of the city as a business (Somoza Medina 2016).

Between 2008 and 2013, the GFC caused the end of the housing boom in Spain and it generated a troubling crisis of public debt and liquidity in the banking system (Fernández Durán 2006). This fact has had several consequences. It caused an extraordinary rise in unemployment, which reached its peak (26.1\% of the active population) in 2013 , gradually decreasing since then. The evolution of unemployment in large cities and medium-sized cities for the period 2006-2012 is an example of the impact caused by the bursting of the financial and real estate bubble and by the neoliberal policies of fiscal austerity applied in the European Union (Méndez Gutiérrez Del Valle 2013). This had a direct impact on local labour markets, population income and quality of life. This is linked to the indebtedness of families, companies, financial entities and public administrations, reducing consumption and increasing the risk of late payment (Romero 2010), which meant an increase in the evictions in Spain, rising from 26,000 to almost 94,000 cases between 2007 and 2010 (Etxezarreta Etxarrri et al. 2012).

Another consequence of the crisis is the shortage of affordable housing for existing wages. No fiscal measures were adopted to curb the real estate development or to regulate prices in order to adapt them to the purchasing power of the population (Pareja Eastway 2010, Rodríguez López 2010). This situation and the level of housing construction generated a huge number of empty and secondary residences while new construction reached its unprecedented peak in Spain. There was an increase in the secondary residence purchase, mainly in tourist areas, related with the foreign investment in housing. According to the census data of the INE (Spanish acronym for the National Institute of Statistics), the proportion of secondary residences, in relation to those registered as main ones in the mid-20th century, was of 3.01 secondary residences for every 100 main dwellings, while at the beginning of the 21 st century this number was 22.78 . Moreover, in 1991 , there were $5,399,254$ empty houses, increasing to $7,124,935$ in 2011 , which represents a growth of more than $30 \%$ of this type of housing. This model generated inequalities and numerous problems for the local people. Some research highlights the existence of greater implications of the crisis for certain population groups that are more vulnerable, such as the young people, the elderly and the migrants (Melo Vieira and Miret Gamundi 2010). The problems of access to housing are incompatible with the existence of these levels of secondary and empty housing, which can be described as a violation of the right to housing.

In the light of the abovementioned information and data, a better understanding of the housing reality is necessary in order to improve access to housing for the population. To this end, the main objective of this paper is to expand and to deepen the understanding of the Spanish housing crisis through a qualitative methodology. Through the analysis of the existing discourses, the limitation of ideas and the lack of alternatives to solve Spanish residential problems become obvious, which explains the perpetuation of a housing system in continuous crisis. In order to understand this scenario, the difficult position of housing in the welfare state due to its peculiar nature has to be born in mind. So as to have a clearer view of the situation, the knowledge of those who work directly with the residential system must be taken into account. According to Allen (2009) and his idea of a housing study freed from the limits of science, the scientific researcher bears no more truth than the knowledge and experience provided by the involved people. For these reasons, this paper focuses on identifying the different stakeholder's discourses on the Spain's housing crisis and their limitations. The results have been based on focused interviews with experts and actors involved in the residential system (Calo 2015). The main issues arising in the interviews are reflections on how to deal with the complexity of a housing system in crisis, viewed through the Spanish context and from various professional perspectives. 


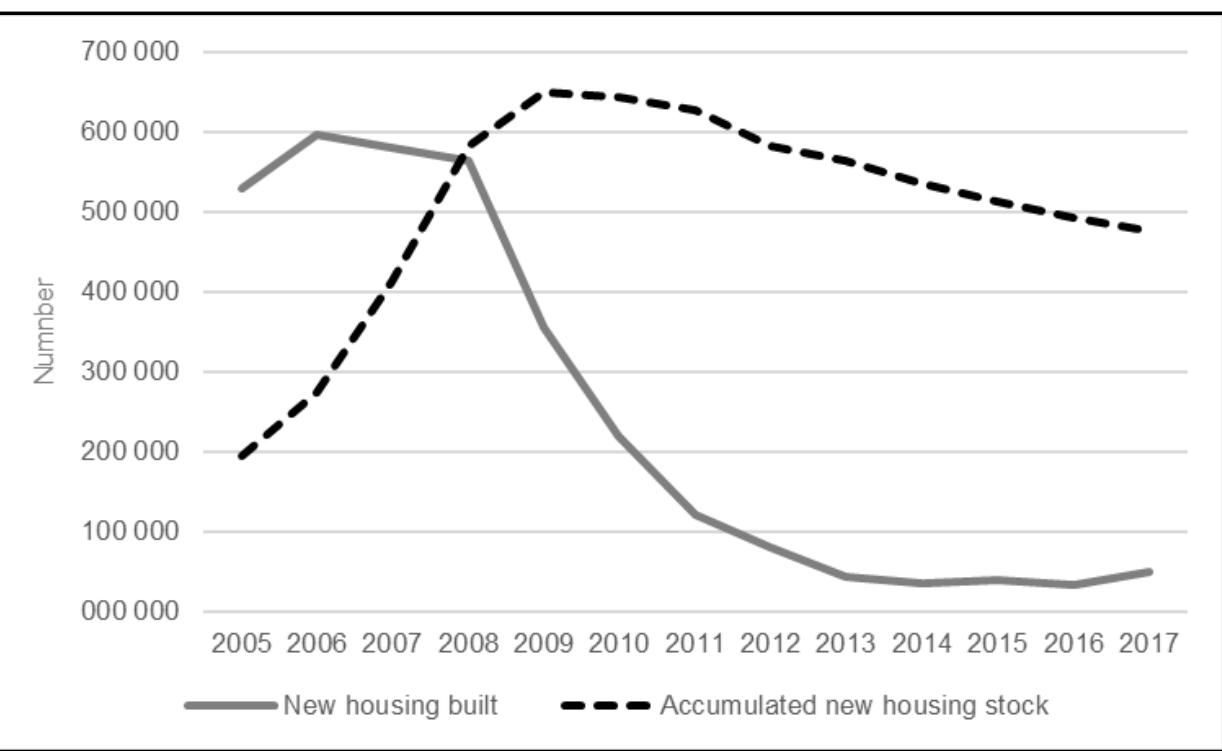

Fig. 1 - Comparison between the number of new housing built and its stock (2005-2017) Source: Ministry of Development (2018)

The first part of this paper offers the framework on which lies the importance of qualitative studies as a methodology for the residential study. Subsequently, the results are organised in three sections: causes of the crisis, consequences of the crisis and possible solutions. Two types of discourses have been identified within these themes: on the one hand, the conservative discourse; on the other hand, the critical one. Through this analysis, the relevance of the discourses is questioned as they replicate ideas that seem out-dated regarding the solution of the housing problem. In order to demonstrate the absence of innovation, the issues that were not raised in the interviews are present in the article. Finally, several conclusions are offered in the form of a summary of the analysed information related to those new policies that seem to make the same mistakes of the past and to those measures that appear to be insufficient.

\section{Methodology}

The importance of discourse analysis in housing studies

Fairclough (1992) suggests that discourse analysis as a research method is needed to understand social reality. From the theoretical point of view, this method recognises the social structures that are related to social action. Methodologically, discourses are an evidence of the roots of structures, relationships and social phenomena. In addition, there are historical reasons which explain why texts are barometers of social processes, movements, and diversity. Moreover, the textual analysis can provide good indicators of social change. Finally, and from a political perspective, texts are evidence of control and domination. In addition, and according to Kemeny (2002), they also show how social problems are built through the state power discourses.

The way of defining social problems is constructed and it causes an empirical reality that limits the concepts that social scientists use to understand it (Kemeny 1992). Through the metanarrative, social problems are raised and defined, and particular policies are developed to solve them (Clapham 2009). The housing policy is therefore the result of the competition of interest 
groups seeking to impose their definition of what a housing problem means and how it should be solved. In order to understand this process, housing studies must be an important part of the qualitative methodology, independently of the quantitative work that can be done, and they must pay attention to the social and cultural context (Kemeny and Lowe 1998).

This kind of studies is quite common in the international literature (Gurstein and Small 2005, Ferrari 2015, Rollwagen 2015, Yust et al. 2015, Manzi and Richardson 2017, Troy et al. 2017, Carder et al. 2018). However, the discourse analysis focused on the study of actors related to Spain's housing crisis is scarce (Fuster et al. 2019). During the crisis, research in Spain was based on quantitative methods (García Montalvo 2007, Leal Maldonado and Domínguez Pérez 2009, Miguel 2009, Naredo and Montiel Márquez 2011, Rodríguez López 2013, López and Rodríguez 2013). For this reason, it is necessary to develop studies like this one that will help to improve the knowledge of the residential situation in Spain through the different existing discourses.

There are different types of discourse analysis; in this paper, the thematic analysis was employed. This type of technique seeks to clarify the corpus of research texts by segmenting them into homogeneous issues until we achieve a topic tree. It aims to identify structures that respond to a specific research question by getting a more in-depth analysis of reality (Braun and Clarke 2006). This method allows us to answer questions on which are the people's concerns on a particular topic. An example of this type of research is the study of Manzi and Richardson (2017) who investigated how the notions of professionalism in housing are being changed by the reduction of the welfare state.

This article offers the thematic analysis of 35 interviews conducted between 2013 and 2015 . Stories from different professional profiles have been collected (Fig. 2). These categories have been chosen according to the categorization carried out by Calo (2015), and based on Cortés Alcalá (1995), who presents different dimensions of the housing system: social, economic and political. Professional categories are representative of each dimension:

- Social: researchers dedicated to the housing analysis from different disciplines by taking social variables such as demographic and social needs into account, and activists focused on the defence of the housing right.

- $\quad$ Economic: people related to different parts of the housing market - real estate agents, developers/builders who own companies dedicated to the housing construction and bank workers.

- Political: politicians and technicians related to the housing sector.

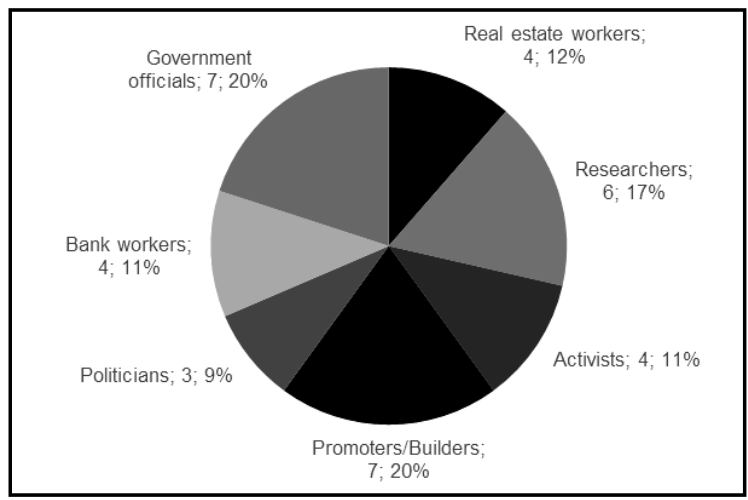

Fig. 2 - Occupation sector of the interviewees

Source: authors' own work 


\section{Results}

In order to better understand the Spanish housing crisis, this paper has analysed the discursive structures that are related to the research question. According to the classification of Braun and Clarke (2006) on the possibilities of the thematic analysis, we have opted for a deductivetheoretical analysis to check the underlying conceptualisation and ideas that have finally been organised within the framework of two ideal types of discourse: the conservative and the critical ones. In doing so, we confront the theoretical background that deals with the causes, consequences and the possible solutions to the housing problems in Spain (Table 1) with the collected data obtained in our interviews.

Table 1

Thematic Discourses on Spain's Housing Crises

\begin{tabular}{|c|c|c|c|}
\hline & $\begin{array}{l}\text { Causes of the } \\
\text { housing crisis }\end{array}$ & $\begin{array}{l}\text { Consequences } \\
\text { of the crisis }\end{array}$ & Solutions \\
\hline \multirow{3}{*}{$\begin{array}{l}\text { CONSERVATIV } \\
\text { E DISCOURSE }\end{array}$} & $\begin{array}{l}\text { Lack of control of } \\
\text { the mortgage } \\
\text { system }\end{array}$ & $\begin{array}{l}\text { Decrease in } \\
\text { housing prices }\end{array}$ & $\begin{array}{l}\text { More comprehensive } \\
\text { regulation of the mortgage } \\
\text { market }\end{array}$ \\
\hline & $\begin{array}{l}\text { Cyclical crises of } \\
\text { capitalism }\end{array}$ & $\begin{array}{l}\text { Drastic reduction } \\
\text { in housing sales }\end{array}$ & $\begin{array}{l}\text { Increase of people's } \\
\text { purchasing power }\end{array}$ \\
\hline & $\begin{array}{l}\text { Construction as } \\
\text { an economic } \\
\text { monoculture }\end{array}$ & $\begin{array}{l}\text { Huge } \\
\text { unemployment } \\
\text { growth }\end{array}$ & $\begin{array}{l}\text { Diversifying Spain's } \\
\text { productivity model }\end{array}$ \\
\hline \multirow{3}{*}{$\begin{array}{l}\text { CRITICAL } \\
\text { DISCOURSE }\end{array}$} & $\begin{array}{l}\text { Mercantilist vision } \\
\text { of housing }\end{array}$ & Rise in evictions & $\begin{array}{l}\text { Enforcement of the right } \\
\text { to housing }\end{array}$ \\
\hline & $\begin{array}{l}\text { Residential system } \\
\text { dependent on bank } \\
\text { financing }\end{array}$ & $\begin{array}{l}\text { Structural prob- } \\
\text { lems of access to } \\
\text { housing }\end{array}$ & Promoting rental housing \\
\hline & $\begin{array}{l}\text { Lack of social and } \\
\text { effective housing } \\
\text { policies }\end{array}$ & $\begin{array}{l}\text { Bankruptcy of the } \\
\text { right } \\
\text { to housing }\end{array}$ & Direct and personal subsidies \\
\hline
\end{tabular}

Source: authors' own work

\section{Causes of the Housing Crisis}

Many authors prefer to avoid the concept of crisis, choosing instead to refer to a long stage of overbuilding or to a real estate bubble (López and Rodríguez 2013). Construction is one of the driving forces for the economy due to its contribution to economic growth, to the GDP and to employment. Moreover, it is an influential sector (García Montalvo 2003, Martín García and González Arias 2011) that absorbs the capital surplus and it stabilizes the economy (Harvey 2008, Lois González et al. 2016). Most of the existing studies indicate that this bubble was a consequence of monetary policy and financial conditions (García Montalvo 2003). As mentioned earlier, while it is true that this situation originated in the United States as a result of the subprime mortgage crisis, the Spanish case has its own features, such as the largest accumulation of housing stock in comparison with other countries, due to an excess of credit with very low interest rates given to builders (García Montalvo 2009, Miguel 2009, Naredo 2010, López and Rodríguez 2013).

Below are outlined the main causes of the crisis as mentioned in the interviews, categorised 
within the conservative and critical types of discourse. According to the conservative discourse, the lack of control of the mortgage and banking system is cited as the main cause of the crisis because of the easy, abundant and cheap bank financing (Burriel de Orueta 2016). This led to an excess of liquidity, which caused unlimited housing investment and resulted in overpricing. When asked about the causes, the most common answers referred to:

The excessive liquidity the bank had meant that they lent around $100 \%$ and $110 \%$ (...). The bank allowed me to take the total amount that I had been given the first day (Promoter/Builder).

The increase in financing for supply and demand with the lowering of interest rates and lengthening of payments (Researcher).

As for the functioning of the economic system in Spain, the construction sector as monoculture, that is, as an almost exclusive driving force for the economy, is mentioned as a cause of the crisis. As it was already stated, Spain had developed an economic model based on the real estate sector (García Montalvo 2009, Naredo 2010, López and Rodriguez 2013). It should be pointed out that, in the early 20th century, the housing market in Spain represented $4 \%$ or $5 \%$ of GDP and $10 \%$ of employment. This implies a short-term financing and planning vision of the economic model for urban growth.

We have an economic model only based on brick (Government Official).

According to the critical discourse, the causes of the crisis are defined in other terms. The exclusive promotion of housing as an economic commodity and investment is profusely mentioned. This is related to the idea of encouraging home ownership through financial instruments (Fields and Hodkinson 2018) and reducing social needs to commercial criteria (Nel -Lo 2019).

The system is based on housing as the capital asset (Researcher).

Housing stopped being a social fixed asset. It is now a business; it went from having a social function to a mercantile function with which to speculate (Activist).

The fact that the economic dimension of housing is promoted implies that the housing system depends solely on banking and on its mortgage or credit financing systems, which is also understood as one of the causes of the crisis by which the social dimension of housing is relegated to the background.

The system is designed by commercial operators (...), by the developers and banks with the support of technicians, and so no new projects are accepted in order to defend the social function of housing (Politician).

Lack of effective policies to defend the social dimension of housing is added to the almost exclusive control of the economic housing sector that depends on banking, so that there were no regulations to stop the crisis (Aalbers 2015).

The policies have been limited to promoting construction. I would not call that a housing policy but a policy of promoting the economic activity of construction (Real state worker). 


\section{Consequences of the crisis}

People's problematic access to housing and the serious economic situation that many households suffer is presented in the housing analysis as one of the most pressing consequences of the housing crisis (García Montalvo 2003). This situation is mainly due to the unequal distribution of wealth created by the rise of unemployment, the lack of market control, a broad lack of liquidity and an increase in debt (García Montalvo 2003, Trilla 2010, Méndez Gutiérrez Del Valle 2013). With this crisis, the households' purchasing power has been severely reduced, which has consequences on the payment of mortgages and on vital processes such as residential independence. With regard to the market level, the most serious consequence is the mismatch between supply and demand, which has led to the decline in prices and housing sales (Rodríguez López 2013), although there is a recovery taking place.

The conservative discourse is focused on the consequences that the housing market suffers, such as the decrease of prices and the reduction of sales. When asked about the consequences of the crisis, some answers pointed to:

The price differences are huge, which shows how inflated they were before, and how much money promoters earned (Government Official).

The lowering of prices and the bankruptcy of the banks because of the crisis (Promoter/Builder).

The reduction in sales, the increase of the rents because of uncertainty and the loss of confidence in the system (Promoter/Builder).

From a conservative point of view, it is also said that unemployment is one of the most important consequences of the crisis with devastating effects on the system and on population, which is stated by some authors such as Méndez Gutiérrez Del Valle (2013).

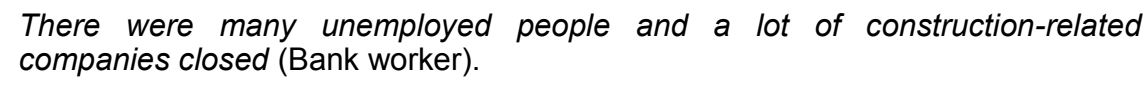

People lost their wages and their jobs, people became unemployed (Real estate worker).

The critical discourse is focused on the consequences for the population in relation to housing, e.g. evictions and the effects they have on the affected families. In this sense, it is important to point out that, in 2007 , the number of foreclosures was fewer than 26,000 , while, in 2010 , they were around 94,000 (Etxezarreta Etxarrri et al. 2012), and, in 2013, this number increased to more than 215,000 (Parreño Castellano et al. 2019).

People are evicted without any consideration; they are losing their house (Promoter/Builder).

People are losing their homes, and not because they have miscalculated, they have been fired (...). People are becoming homeless and in debt (Government Official).

Apart from the eviction-related problems mentioned above, another serious consequence is the widespread difficulty for the population to access housing, mainly for some population groups such as the young, the elder and the migrants (Melo Vieira and Miret Gamundi 2010).

The access problems generated by intermediaries have increased, more and 
more people are struggling to find a home (Researcher).

Access is the problem. We have to help those who cannot access housing because the situation is unsustainable for many people (Government Official).

Everything described above implies a weakening in the right to housing. The fact that the economic dimension of housing has prevailed has meant that the social dimension of housing as a fundamental basic need and right has been pushed into the background.

The right to property is more important than the right to housing. We must redesign the model, re-naturalize and implement the right to housing (Researcher).

\section{Solutions}

Etxezarreta Etxarri et al. (2012) indicate that institutional responses in Europe can be divided in relation to the type of welfare state. The social democrats such as Denmark and Sweden, and the corporatists such as the Netherlands and France opted for a higher degree of protection for income and rental housing. In liberal states like the United Kingdom and the southern states, Spain and Italy, this level of protection was not developed, causing a greater problem of late payments and evictions. In Spain, it is worth highlighting the reform enforced to speed up evictions in the rental housing market and the application of a Code of Good Practices for financial entities, with the aim of protecting mortgage debtors without resources (Etxezarreta Etxarrri et al. 2012).

According to some authors, the solutions to housing problems must imply introducing innovations in housing policies that are adapted to new circumstances through rent and rehabilitation (Trilla 2010). Other policies have an impact on soil legislation and the reconceptualisation of the home dweller's relationship with housing (García Montalvo 2003) or protected housing, which must be considered mainly for rent. Measures are also proposed to ensure an affordable housing price (Clavell Nadal 2007), a greater efficiency through more personal aid and a change in fiscal policies (Fernández Carbajal 2004).

It should be noted that when interviewees were asked for solutions during the in-depth interviews, the response was homogeneous: the difficulty of the issue requires individual actions rather than definitive solutions.

From a conservative perspective, the need to take different actions to correct the market arises. On the one hand, a better regulation of the credit system will in turn increase people's purchasing power. A more realistic system that facilitates credit with greater control of conditions, and one that improves the user's liquidity so that they can access the purchase of a house, must be put in place.

Credit must be facilitated, but with more control and limits, so that the same thing does not happen again (Real estate worker).

We must seek stable control measures of the credit system to promote the market with less institutional interference and to achieve a consequent private initiative (Researcher).

On the other hand, it seems necessary to change the model of economic growth to enhance employment. This shift would also avoid the "monoculture" of the construction industry and improve other more productive nature industrial sectors. In this way, the labour market would not be so dependent on construction, and, in times of crisis in this sector, the effects on 
unemployment will be lower.

It is necessary to obtain a change of the economic model, to obtain a model of development less based on construction and on tourism (Activist).

The critical discourse is more oriented towards measures referring to the need for a change in housing policies. The first one is the real implementation of the right to housing with global and stable policies. The right to housing is recognised, but not enforced on many levels. For this reason, it was essential for many of those interviewed to make a change in the policies that directly take this right into account and to defend the social function of housing as a basic need, through issues such as the promotion of rent as well as protected rents, and the rehabilitation of real estate. Housing protection should be more oriented to renting than to owning in order to generate a stock of public housing that actually fulfils its social function at any given time.

It is necessary to obtain a professionalised rental market with public, semi-public or private entities, and to expand measures for restoration (Promoter/Builder).

There is a very good solution for Spain's housing stock: that banks themselves generate a rental real estate agency, and not simply wanting to give them [houses] away as they are giving them away. Public rental and private rental companies must be encouraged through legislation (Government Official).

Direct and personal subsidies, together with more fiscal control measures, are also understood as necessary. In order to make the use of subsidies effective, they should come from a personal and direct nature. Thus, the tax system must be modified.

Subsidies must be given to those who need them and for the length of time they need them, together with a list of home seekers (Politician).

\section{Discussion}

\section{Nothing new on the horizon}

At this point, it can be noticed that what has been said in the interviews is not especially new. The conservative discourse focuses on the economic dimension of the housing while the critical one seems to favour the social dimension. Nevertheless, the ideas expressed do not offer innovations. Because of this, it has been decided to describe a number of topics that have not been discussed before or which have not been dealt with in the interviews. However, they have been raised in the research on housing and they seem to be of vital importance for the future of the housing system. A possible explanation for these absences is that these issues have not become part of the social policy (Jacobs and Manzi 1996) yet, which indicates that the interviewees' discourse is aligned with the institutional discourses.

In the outlined discourses, there is no mention of sustainability. On the one hand, the environmental and unsustainable consequences, such as the uncontrolled soil occupation, together with wide material, energy and land exploitation, have not been mentioned (Naredo and Montiel Márquez 2011). On the other hand, when the interviews were conducted (20132015), the construction of new housing was on the rise again. In this sense, the so-called "degrowth" thesis postulates a reduction in the activity of some traditional industrial sectors where construction is found (Taibo 2009). The aim is not to stop building, but to reorient the construction activity towards more sustainable processes such as building rehabilitation, urban regeneration and the updating of homes to convert them into "lower energy consumption and lower greenhouse gas emission spaces" (Cuchí and Sweatman 2011: 6). By renewing and taking advantage of the space built with eco-efficient and environmentally friendly criteria, we 
could reduce the consumption of soil, materials, energy, waste and pollution emissions.

Another issue that has not been raised in the interviews is the alternative to housing access, which has been gaining prominence in the last few years (López-Bahut 2016, Sala 2018). Spain's housing policy has generated a system that is based almost exclusively on the freehold property. Rental and subsidised housing are the other existing alternatives (Calo 2014). There seems to be nothing beyond the pairing owning/renting or freehold/subsidised. However, other processes that do not seem to be significant have appeared or increased during the crisis.

For example, the collective processes for housing access are increasing. Bottom-up participatory processes caused by the change in the social context are being generated and they embrace several different aspects, from politics to city life. The inhabitants stop playing a passive role and take an active part on different levels of participation in the architectural definition, design, construction or management (Morales Soler et al. 2012). Within these collective models, co-housing, which seeks a cooperative assembly and democratic process, stands out together with squatting, based on the occupation of empty houses (López-Bahut 2016).

After the last crisis, which has been temporarily placed between 2008 and 2013 in this paper, and after its global effects on housing, it is necessary to rethink its role in society through multidisciplinary and multi-methodological studies. In housing studies, qualitative methods should be taken into account to broaden concepts and to better understand the social context in which they are built (Kemeny 1992, Kemeny and Lowe 1998). In order to fulfil this premise, this paper was based on the discourse analysis to understand the crisis from a more rational point of view (Kemeny 2002), to recognize power relations (Jacobs and Manzi 1996) and to broaden the approach of the analysis of Spain's housing crisis.

\section{Conclusions}

The thematic discourse analysis of 35 focused interviews has been employed, and the text corpus has been divided into three homogeneous thematic blocks: the main causes of the housing crisis, the main consequences of it and possible solutions. Moreover, different discursive structures have been identified and categorised into two ideal types of discourses: the conservative discourse and the critical one.

The conservative discourse has a more traditional approach, closer to the dominant discourse. It assumes that crises are cyclical, finding the biggest problem of the last one in the rupture of the existing system, the mismatch between supply and demand and the lowering of prices. Although it is understood that the responsibility for this situation is shared, the financial sector is more specifically singled out because it does not control financing. The solutions to this situation must involve improving the regulation of the credit system that facilitates lending, increasing the purchasing power, changing the model of economic growth and improving employment to facilitate the access to housing.

The critical discourse offers a deeper analysis of the current housing system. It describes the functioning of the housing system as dependent on the economic one, which implies imbalance and instability in the people's housing access. In this sense, public administrations should monitor the functioning of the system and protect the right to housing. From the point of view of this discourse, the main problem of housing access is the absence of policies that are socially effective, and the dependence on banking. The solution to this situation is that it must inevitably go through a structural change, focusing on the real implementation of the right to housing with global and stable policies, and on socially oriented subsidies and fiscal measures with greater control. 
A number of topics not mentioned in the interviews have also been introduced: sustainability, "de-growth" and collective housing access processes. These absences during the interviews may have been due to the fact that these issues are still not part of the collective imaginary, as they are currently side topics, although they are likely to become part of the most critical social discourse in the future. The latest Spanish Housing Act (2018-2021) is a representation of this lack of innovation. The measures in this program maintain historical action lines: help for mortgages and help for rents and rehabilitation. On the one hand, subsidies for evicted people represent a necessary measure to correct the effects of the crisis. On the other hand, measures aimed at sustainability and energy efficiency seem to be the most innovative orientation.

To sum up, in 2015 - when the fieldwork was completed - the existing discourse on Spain's housing crisis could be categorised into two types. On the one hand, the conservative discourse that is focused on the economic dimension of housing as merchandise aims to correct the system and it seems to be more coordinated with the institutional discourse. On the other hand, the more critical discourse is oriented towards the social dimension of housing as a fundamental right, and it is likely to advance. Notwithstanding, what is clear is that a change should be achieved in order to correct what seems a cyclical crisis. The ideas in the common imaginary are mainly those that the stakeholder elaborates. Even the critical discourses have no new proposals. The "de-growth", collective housing access processes or bottom-up processes, such as co-housing, are increasing, but not enough to change the existing discourses during Spain's housing crisis.

\section{References}

AALBERS M. B. (2015), The Great Moderation, the Great Excess and the global housing crisis, International Journal of Housing Policy 15 (1), 43-60.

ALLEN C. (2009), The fallacy of "housing studies": philosophical problems of knowledge and understanding in housing research, Housing, Theory and Society 26 (1), 53-79.

BERMEJO LATRE J. L. (2010), La evolución de las políticas de vivienda en la España del siglo XX, in: López Ramón F. (ed.), Construyendo el Derecho a la Vivienda, Marcial Pons, Madrid, pp. 165-196.

BRAUN V., CLARKE V. (2006), Using thematic analysis in psychology, Qualitative Research in Psychology 3 (2), 77-101.

BURRIEL DE ORUETA E. L. (2016), Empty urbanism: the bursting of the Spanish housing bubble, Urban Research \& Practice 9 (2), 158-180.

CALO E. (2014), Vivienda y territorio en España, in: Lamela C., Cardesín Diaz J. M., García Docampo M. (eds.), Dinámicas territoriales en España: problemas y tendencias en la estructura y ordenación del territorio, Biblioteca Nueva, Madrid, pp. 171-200.

CALO E. (2015), El sistema residencial en España: componentes, funcionamiento y necesidades de vivienda, Universidade da Coruña, Retrieved from: www.ruc.udc.es.

CARDER P. C., KOHON J., LIMBURG A., BECKER E. (2018), Waiting for housing assistance: characteristics and narrative accounts of low-income older persons, Housing and Society 45 (2), 63-80.

CASTELLS M. (2004), La cuestión urbana, Siglo XXI, Madrid.

CLAPHAM D. (2009), Introduction to the special issue - a theory of housing: problems and potential, Housing, Theory and Society 26 (1), 1-9.

CLAVELL NADAL D. (2007), Una política de vivienda innovadora: la experiencia de Cataluña, ACE: Arquitectura, Ciudad y Entorno 2 (5), 497-506.

CORTÉS ALCALÁ L. (ed.) (1995), Pensar la vivienda, Talasa, Madrid.

CORTÉS ALCALÁ L. (1997), Hablando sobre la exclusión residencial, Cáritas, Madrid.

CUCHÍ A., SWEATMAN P. (2011), Una visión-país para el sector de la edificación en España: hoja de ruta para un nuevo sector de la vivienda, GBCE, Fundación Conama, Madrid. 
ESPING-ANDERSEN G. (1990), The three worlds of welfare capitalism, Princeton University Press, New Jersey.

ETXEZARRETA ETXARRRI A., HOEKSTRA J., DOL K., CANO FUENTES G. (2012), De la burbuja inmobiliaria a las ejecuciones hipotecarias, Ciudad y Territorio. Estudios Territoriales (CyTET) 44 (174), 597-613.

FAIRCLOUGH N. (1992), Discourse and text: linguistic and intertextual analysis within discourse analysis, Discourse \& Society 3 (2), 193-217.

FERNÁNDEZ CARBAJAL A. (2004), Veinticinco años de política de vivienda en España (1976-2001): una visión panorámica, Información Comercial Española 816, 145-161.

FERNÁNDEZ DURÁN R. (2006), El Tsunami urbanizador español y mundial: Sobre sus causas y repercusiones devastadoras, y la necesidad de prepararse para el previsible estallido de la burbuja inmobiliaria, Virus, Barcelona.

FERRARI E. (2015), The social value of housing in straitened times: the view from England, Housing Studies 30 (4), 514-534.

FIELDS D. J., HODKINSON S. N. (2018), Housing Policy in Crisis: An international perspective, Housing Policy Debate 28 (1), 1-5.

FUSTER N., ARUNDEL R., SUSINO J. (2019), From a culture of homeownership to generation rent: housing discourses of young adults in Spain, Journal of Youth Studies 22 (5), 585-603.

GAJA I DÍAZ F. (2013), Tras el tsunami inmobiliario. Salir del atolladero, in: Observatorio Metropolitano de Madrid (eds.), Paisajes devastados. Después del ciclo inmobiliario: impactos regionales y urbanos de la crisis, Traficantes de Sueños, Madrid, pp. 313-353.

GARCÍA MONTALVO J. (2003), La vivienda en España: desgravación, burbujas y otras historias, Perspectivas del Sistema Financiero 78, 1-43.

GARCÍA MONTALVO J. (2006), Deconstruyendo la burbuja: expectativas de revalorización y precios de la vivienda en España, Papeles de Economía Española 109, 44-75.

GARCÍA MONTALVO J. (2007), Algunas consideraciones sobre el problema de la vivienda en España, Papeles de Economía Española 113, 138-153.

GARCÍA MONTALVO J. (2009), Financiación inmobiliaria, burbuja crediticia y crisis financiera: lecciones a partir de la recesión 2008-2009, Papeles de Economía Española 122, 66-85.

GURSTEIN P., SMALL D. (2005), From housing to home: reflexive management for those deemed hard to house, Housing Studies 20 (5), 717-735.

HARVEY D. (2008), The right to the city, New Left Review 53, 23-40.

JACOBS K., MANZI T. (1996), Discourse and policy change: the significance of language for housing research, Housing Studies 11 (4), 543-560.

KEMENY J. (1992), Housing and social theory, Routledge, London and New York. -195 .

KEMENY J. (2002), Society versus the state, Housing, Theory and Society 19 (3-4), 185

KEMENY J., LOWE S. (1998), Schools of comparative housing research: from convergence to divergence, Housing Studies 13 (2), 161-176. Madrid.

LEAL MALDONADO J., CORTÉS ALCALÁ L. (1995), La Dimensión de la Ciudad, CIS,

LEAL MALDONADO J., DOMÍNGUEZ PÉREZ M. (2009), Pasado y futuro del parque de viviendas de Madrid: despejando incertidumbres, Urban 14, 80-91.

LOIS GONZÁLEZ R. L., PIÑEIRA MANTIÑAN M. J., VIVES MIRÓ S. (2016), The urban bubble process in Spain: an interpretation from the theory of the circuits of capital, Journal of Urban and Regional Analysis 8 (1), 5-20.

LÓPEZ-BAHUT E. (2016), Alternativas en la vivienda colectiva desde la autogestión de la ciudadanía. Diferentes casos de estudio en España, II Congreso Internacional de Habitaçao Colectiva Sustentável, 718-723.

LÓPEZ I., RODRÍGUEZ E. (2013), Competitividad territorial y circuito secundario de 
acumulación. El paroxismo de un caso: el ciclo español de 1995-2007, Observatorio Metropolitano de Madrid (eds.), Paisajes devastados después del ciclo inmobiliario: impactos regionales y urbanos de la crisis, Traficantes de Sueños, Madrid, pp. 25-75.

MANZI T., RICHARDSON J. (2017), Rethinking professional practice: the logic of competition and the crisis of identity in housing practice, Housing Studies 32 (2), 209-224.

MARTIN R. (2011), The local geographies of the financial crisis: from the housing bubble to economic recession and beyond, Journal of Economic Geography 11 (4), 587-618. MARTÍN GARCÍA R., GONZÁLEZ ARIAS J. (2011), Análisis estratégico de la industria de la construcción en España, Cuadernos de Gestión 11 (1), 141-161.

MELO VIEIRA J., MIRET GAMUNDI P. (2010), Transición a la vida adulta en España: una comparación en el tiempo y en el territorio utilizando el análisis de entropía, Revista Española de Investigaciones Sociológicas 131, 75-107.

MÉNDEZ GUTIÉRREZ DEL VALLE R. (2013), Crisis económica, vulnerabilidad urbana y desempleo en España, Ciudad y Territorio. Estudios Territoriales (CyTET) 45 (178), 649-667. MIGUEL M. (2009), La crisis inmobiliaria, Economistas 27 (119), 256-264.

MÓDENES J. A., LÓPEZ-COLÁS J. (2014), Cambio demográfico reciente y vivienda en España: ¿hacia un nuevo sistema residencial?, Revista Española de Investigaciones Sociológicas 148, 103-134.

MORALES SOLER E., ALONSO MALLÉN R., MORENO CRUZ E. (2012), La vivienda como proceso. Estrategias de flexibilidad, Hábitat y Sociedad 4, 33-54.

NAREDO J. M. (2010), El modelo inmobiliario español y sus consecuencias, Boletín $\mathrm{CF}+\mathrm{S} 44,13-27$.

NAREDO J. M., MONTIEL MÁRQUEZ A. (2011), El modelo inmobiliario español y su culminación en el caso valenciano, Licaria Antrazyt, Barcelona.

NEL-LO O. (2019), Los retos de la ciudad contemporánea, Posición 2, 1-10.

PAREJA EASTWAY M. (2010), El régimen de tenencia de la vivienda en España, in: Leal Maldonado J. (ed.), La política de vivienda en España, Pablo Iglesias, Madrid, pp. 129166.

PARREÑO CASTELLANO J. M., DOMÍNGUEZ MUJICA J., ARMENGOL MARTÍN M. T., BOLDÚ HERNÁNDEZ J., PÉREZ GARCÍA T. (2019), Real estate dispossession and evictions in Spain: a theoretical geographical approach, Boletín de la Asociación de Geógrafos Españoles 80, 2602, 1-25.

RODRÍGUEZ LÓPEZ J. (2010), La oferta de vivienda en España, in: Leal Maldonado L. (ed.), La política de vivienda en España, Pablo Iglesias, Madrid, pp. 75-100.

RODRÍGUEZ LÓPEZ J. (2013), La vivienda. De los ajustes al Banco Malo, Economistas 31 (135), 227-237.

ROLLWAGEN H. (2015), Constructing renters as a threat to neighbourhood safety, Housing Studies 30 (1), 1-21.

ROMERO J. (2010), Construcción residencial y gobierno del territorio en España. De la burbuja especulativa a la recesión. Causas y consecuencias, Cuadernos Geográficos 47 (2), $17-46$.

SALA E. (2018), Crisis de la vivienda, movimientos sociales y empoderamiento: una revisión sistemática de la literatura, Documents d'Anàlisi Geogràfica 64 (1), 99-126. Aires.

SASSEN S. (1999), La ciudad global: Nueva York, Londres, Tokio, Eudeba, Buenos

SASSEN S. (2004), Los espectros de la globalización, Fondo de Cultura Económica, Buenos Aires.

SOMOZA MEDINA X. (2016), Governance, urban competitiveness and crisis in Spain, Journal of Urban and Regional Analysis 8 (1), 47-60. Bilbao.

TAIBO C. (2009), Decrecimiento, crisis, capitalismo, Universidad del País Vasco,

TRILLA C. (2010), Una reflexión sobre el modelo español de política de vivienda, in: Leal Maldonado J. (ed.), La política de vivienda en España, Pablo Iglesias, Madrid, pp. 129- 
166.

TROY L., EASTHOPE H., RANDOLPH B., PINNEGAR S. (2017), 'It depends what you mean by the term rights': strata termination and housing rights, Housing Studies 32 (1), 1-16.

VAN WAEYENBERGE E. (2018), Crisis? What crisis? A critical appraisal of World Bank housing policy in the wake of the global financial crisis, Environment and Planning A: Economy and Space 50 (2), 288-309.

YUST B. L., URNESS M., MITCHELL D., WEBER W. G., LOOSEN A. (2015), A qualitative assessment of experiences with selected green technologies in affordable multifamily housing, Housing and Society 42 (3), 239-249.

Initial submission: 30.01 .2020

Revised submission: 23.11 .2020

Final acceptance: 21.12 .2020

Correspondence: Facultade de Socioloxía, Universidade da Coruña, Campus Elviña s/n, 15071 A Coruña, Galicia, Spain.

Email: estefania.calo@udc.es 
